\title{
Human Leukocyte Interferon Treatment of Two Children with Insulin Dependent Diabetes
}

\author{
K. H. Rand ${ }^{1,3,4,5}$, A. L. Rosenbloom ${ }^{2}$, N. K. Maclaren ${ }^{2,3}$, J. H. Silverstein ${ }^{2}$, W. J. Riley ${ }^{2}$, B. E. Butterworth ${ }^{6}$, \\ J. W. Yoon ${ }^{7}$, A. H. Rubenstein ${ }^{8}$ and T. C. Merigan ${ }^{9}$ \\ Departments of ${ }^{1}$ Medicine, ${ }^{2}$ Pediatrics, ${ }^{3}$ Pathology and ${ }^{4}$ Immunology and Medical Microbiology, J. Hillis Miller Health Center, \\ The Shands Teaching Hospital, ${ }^{5}$ Gainesville Veterans Administration Hospital, University of Florida, Gainesville, Florida, \\ ${ }^{6}$ Chemical Industry Institute of Toxicology, Research Triangle Park, North Carolina, ${ }^{7}$ National Institute of Dental Research, \\ National Institutes of Health, Bethesda, Maryland, ${ }^{8}$ Department of Medicine, University of Chicago, Chicago, Illinois, \\ and ${ }^{9}$ Department of Medicine, Stanford University School of Medicine, Stanford, California, USA
}

\begin{abstract}
Summary. Two patients with newly diagnosed insulin dependent diabetes mellitus were treated with human leukocyte interferon based on the hypothesis that the diabetes was induced by an active viral infection in the pancreatic islets and could be arrested. High peak levels of serum interferon were achieved (100-200 U/ml) with minimal systemic side effects. There was no sustained therapeutic benefit as measured by increased production of endogenous insulin, or of C-peptide, or by a lower requirement for exogenous insulin. Further trials with interferon treatment should be undertaken only if evidence of active viral infection (culture, antigen detection) can be associated with insulin dependent diabetes onset and these markers followed during treatment.
\end{abstract}

Key words: Insulin dependent diabetes mellitus, interferon, virus, C-peptide.

The hypothesis that insulin dependent diabetes mellitus results from a viral infection of the pancreatic islet cells is founded on epidemiological observations [1-5], as well as individual case studies [6-9]. Human leukocyte interferon has a wide range of antiviral activity and has been used successfully in the treatment of chronic active hepatitis B [10] and acute herpes zoster [11]. Therefore, the possibility exists that early in the course of insulin dependent diabetes an appropriate antiviral agent might modify the process of virus induced pancreatic B cell injury. Even if only a percentage of $B$ cells could be retained in a functional state, the additional endogenous insulin would be beneficial [12].

\section{Materials and Methods}

Human leukocyte interferon was obtained from Dr Kari Cantell, State Serum Institute, Helsinki, Finland. It was produced, partially purified and safety tested as described elsewhere [11, 13]. The specific activity was $1 \times 10^{6}$ International Reference units/mg protein. Serum interferon levels were assayed by plaque reduction assay using vesicular stomatitis virus in human diploid fibroblasts [14].

Serum immunoreactive insulin was measured by radioimmunoassay. Plasma and urine glucose levels were measured by enzymatic methods, Haemoglobin $\mathbf{A}_{1}$ by commercial kit (Isolab), and fasting and stimulated C-peptide by specific radioimmunoassay [15]. Autoantibodies against pancreatic islet cells were determined by the indirect fluorescent antibody method [16] and by the complement fixing indirect fluorescent method [17].

Antibodies to Coxsackie B1-6 were measured by a microtitre neutralization method, using prototype strains as described by Yoon et al [6]. For the 3 weeks of study, daily throat and stool specimens from both patients were inoculated into human diploid foreskin fibroblasts and into primary rhesus monkey kidney cells (Flow Laboratories, McLean, Virginia) for case 1, and into human foreskin fibroblasts, a continuous rhesus monkey kidney cell line (LLC-MK ${ }_{2}$ ) and the Mason-Darbin canine kidney cell lines (Flow Laboratories, McLean, Virginia, USA) for case 2. All cultures were observed two to three times a week for viral cytopathic effects and held for 3 weeks before being discarded as negative. All cultures were tested for haemadsorption with guinea-pig erythrocytes between 14-21 days.

\section{Patients}

Informed consent was obtained from the parents of both patients.

\section{Patient 1}

A 9-year-old Caucasoid female was admitted to a local hospital on 16 July, 1979 with a 2-week history of polyuria and polydipsia. For the 2 days before admission she complained of abdominal pain, and then developed Kussmaul breathing. Physical examination on admission, including height and weight, was normal. Plasma glucose level was $50.2 \mathrm{mmol} / \mathrm{l}$, serum acetone was positive and $\mathrm{CO}_{2}$ combining power $9 \mathrm{mmol} / 1$. Ketoacidosis was readily controlled and she was discharged 24 July taking $35 \mathrm{U}$ isophane insulin every morning, reduced to $19 \mathrm{U} /$ day over the next month. In the Clinical Research Center, Shands Teaching Hospital from 17 August, the dose of insulin was reduced over 3 days and stopped. After 2 days without exogenous insulin, she was given interferon, $1.5 \times 10^{5} \mathrm{U}$ $\mathrm{kg}^{-1} \mathrm{day}^{-1}$ in divided doses by SC injection every $12 \mathrm{~h}$. This dosage was similar to that used in previous studies of interferon therapy for herpes zoster [11]

During the first week, while receiving interferon, fasting morning plasma glucose levels rose from a baseline range of 7.2-10 to 


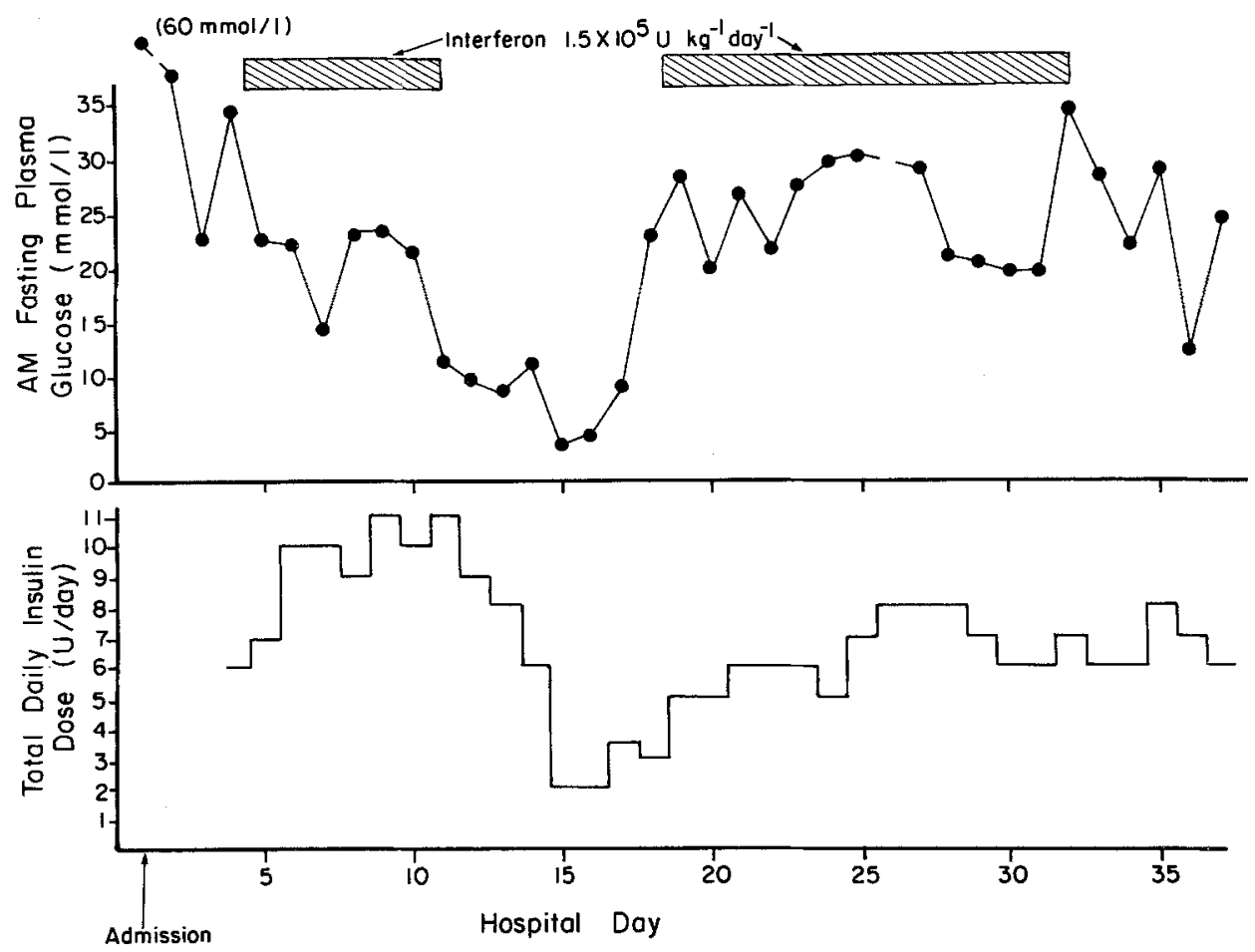

Fig. 1. Relationship of daily morning fasting plasma glucose level and total daily insulin dose to the administration of human leukocyte interferon (shown by bars at top) in patient 2, a 6-month-old Caucasoid female

$15.3-16.7 \mathrm{mmol} / 1$ with a relatively low (estimated $800-1000$ kcal) daily food intake. In the second week, during which no interferon was given, fasting morning glucose levels remained in the same range. During the third week, while she was receiving interferon, fasting glucose levels remained high, acetone appeared in the serum, and 24-h glucose excretion in the urine rose to $100-200 \mathrm{~g} /$ day. One hour post-prandial plasma glucose level was above $28 \mathrm{mmol} / \mathrm{l}$ after day 5 of interferon and she was restarted on isophane insulin, $8-10 \mathrm{U} /$ day. Over the subsequent year, she remained well and active using $21-35 \mathrm{U}$ isophane insulin/day $\left(0.60-1.0 \mathrm{U} \mathrm{kg}^{-1} \mathrm{day}^{-1}\right)$. The only side effects of the interferon were a fever of $38.6{ }^{\circ} \mathrm{C} 8 \mathrm{~h}$ after the first dose, and depression of the total leukocytes to $2500 \mathrm{~mm}^{3} 4$ days after beginning the first course of interferon and to $2900 \mathrm{~mm}^{3} 5$ days after beginning the second week of interferon. The leukocyte count promptly returned to normal after interferon was stopped. There were no abnormalities of liver function or platelet count. Except for malaise associated with fever on the first day of interferon, the patient experienced no subjective side effects during either course of interferon.

\section{Patient 2}

A 6-month-old Caucasoid female was admitted to Shands Teaching Hospital 12 March, 1980 with a $24 \mathrm{~h}$ history of polyuria, polydipsia, vomiting, and fever. She had been a healthy first-child of a normal pregnancy, labour and delivery. A maternal uncle had developed insulin dependent diabetes at age 19 years. The left tympanic membrane was dull, the right red and bulging, and she had a nappy rash. She was at the 50th percentile for height and weight. Initial plasma glucose level was $60 \mathrm{mmol} / 1$, plasma acetone was positive at $1: 32$ and the $\mathrm{CO}_{2}$ combining power was $5 \mathrm{mmol} / \mathrm{l}$. Ketoacidosis was controlled rapidly and isophane insulin given the second day in the hospital.
On the third hospital day, approximately $90 \mathrm{~h}$ after the onset of polyuria and polydipsia, human leukocyte interferon treatment was begun at a dose of $1.5 \times 10^{5} \mathrm{U} \mathrm{kg}^{-1} \mathrm{day}^{-1} \mathrm{SC}$ in divided doses every $12 \mathrm{~h}$. During week 1 , she required approximately $5 \mathrm{U}$ isophane insulin in the morning and $1 \mathrm{U}$ of crystalline insulin at night, with glycaemia in the range of $17-28 \mathrm{mmol} / 1$ (Fig. 1). After one week, interferon was withheld, and a transient but dramatic fall in insulin requirements occurred 4-5 days later. However, insulin requirements were clearly rising at the time interferon was restarted. While receiving interferon over the next 2 weeks, her insulin requirements and fasting and post-prandial plasma glucose levels remained high. No fall in insulin requirement occurred in the week following the second 2-week course of interferon. Except for a fever of $38.8^{\circ} \mathrm{C} 9 \mathrm{~h}$ after the first dose of interferon, and a transient episode of erythema and swelling at some of the injection sites, there was no evidence of an adverse reaction to the interferon. Blood leukocytes, platelets, and serum glutamic oxylacetate transaminase monitored twice weekly throughout the 5 week hospitalization, remained normal. She was discharged 1 week after the last dose of interferon, requiring $5 \mathrm{U}$ isophane with $1 \mathrm{U}$ crystalline insulin at night and has remained well on similar dosage.

\section{Results}

\section{Interferon}

High peak levels of serum interferon were attained. In patient 1 , the mean peak level was $112 \pm 10 \mathrm{U} / \mathrm{ml}$ in week 1 and $218 \pm 10 \mathrm{U} / \mathrm{ml}$ in week 2 of interferon treatment (mean \pm SD of three determinations $5 \mathrm{~h}$ 
after SC injection). Corresponding values for patient 2 were as follows: in the first week 113 and $86 \mathrm{U} / \mathrm{ml}$ (average 99.5) and in the second week 90.5 \pm $30.8 \mathrm{U} / \mathrm{ml}$ (mean $\pm \mathrm{SD}$ of four determinations $4 \mathrm{~h}$ after injection).

The side effects of interferon were minimal. Both patients had a febrile response beginning about $6 \mathrm{~h}$ after the initial dose, but both quickly became afebrile and remained clinically well and active during the remainder of therapy. Aside from a mild and reversible depression of the blood leukocyte counts in patient 1 , there was no laboratory evidence of toxicity.

\section{Viral Study}

In patient 1 , serum antibody to Coxsackie $\mathrm{B} 4$ showed a microneutralization titre of $1: 256,24$ days after her initial hospitalization for diabetic ketoacidosis, which was 14 days before treatment with interferon. Neutralization titres to Coxsackie viruses B2, B5, and $\mathrm{B} 6$ were all less than 8 , to Coxsackie $\mathrm{B} 1,1: 32$, and to Coxsackie B3, 1:8. No fourfold rises or falls occurred over the next month. There was no serological evidence of recent infection by mumps, mycoplasma, adenovirus or leptospirosis.

In patient 2, serum neutralizing antibody to Coxsackie B4 was $1: 32,2$ days after the onset of symptoms, and was $1: 163$ weeks later. Serum neutralizing antibodies to Coxsackie B5 were between 1:20 and 1:40 and did not change over the next 3 weeks. Acute and convalescent titres to Coxsackie B1, B2, B3 and B6 were all less than 1:20. However, both the patient's mother and father had high $(\geq 1: 512)$ but stable neutralizing titres to Coxsackie B4.

No viruses were isolated from either patient despite daily throat and stool cultures for 3 weeks.

\section{Pancreatic Islet Cell Antibody}

Islet cell antibody was present $(2+$ undiluted $)$ in patient 1, 24 days after her episode of diabetic ketoacidosis, and persisted without change over the next 30 days. The antibody was absent in patient 2 , two days after onset of diabetic ketoacidosis but appeared in low titre on days $9,16,23$, and 30 .

C-Peptide. C-peptide measurements during interferon therapy were as follows: patient 1 before interferon: $0.31 \mathrm{pg} / \mathrm{ml}$ (fasting) and $1.01 \mathrm{pg} / \mathrm{ml}(1 \mathrm{~h}$ postprandial; receiving interferon, week $1: 0.49 \mathrm{pg} / \mathrm{ml}$ (fasting) and $0.56 \mathrm{pg} / \mathrm{ml}$ ( $1 \mathrm{~h}$ postprandial); off interferon $0.46 \mathrm{pg} / \mathrm{ml}$ fasting; during interferon (week 2) $0.12 \mathrm{pg} / \mathrm{ml}$ (fasting) and $0.12 \mathrm{pg} / \mathrm{ml}(1 \mathrm{~h}$ post-prandial). Corresponding values for patient 2 were: before interferon $0.12 \mathrm{pg} / \mathrm{ml}$ (fasting) and $0.18 \mathrm{pg} / \mathrm{ml}$ ( $1 \mathrm{~h}$ post-prandial), during interferon (week 1) $0.06 \mathrm{pg} / \mathrm{ml}$ (fasting) and $0.12 \mathrm{pg} / \mathrm{ml}(1 \mathrm{~h}$ postprandial), off interferon $0.06 \mathrm{pg} / \mathrm{ml}$ (fasting) and $0.06 \mathrm{pg} / \mathrm{ml}(1 \mathrm{~h}$ post-prandial), and on interferon (week 2) $0.06 \mathrm{pg} / \mathrm{ml}$ (fasting) and $0.06 \mathrm{pg} / \mathrm{ml}(1 \mathrm{~h}$ post-prandial).

\section{Discussion}

Two patients with newly diagnosed insulin dependent diabetes were treated with human leukocyte interferon, with no persistent improvement in fasting blood glucose levels or endogenous insulin production whether measured by direct radioimmunoassay of insulin or of C-peptide.

There are several explanations for a lack of effect of interferon in our patients. (1) Their diabetes may not have been of viral aetiology. For example, several studies have been unable to implicate any viral agent in insulin dependent diabetes [18-21]. (2) Their diabetes might have been the result of a viral infection in the pancreatic islet cells, but the disease may not have appeared until after active infection was terminated by the immune response. (3) Since interferon only protects uninfected cells, too few uninfected $B$ cells might have remained by the time insulin dependent diabetes was apparent. (4) The viral agent of insulin dependent diabetes may be unresponsive to interferon, although most human viruses appear to be quite susceptible in the laboratory. For example, in a recent study of the effect of interferon on prevention of dissemination of herpes zoster, protection was dose related and seemed to require serum interferon levels in the range of $200-400 \mathrm{U} /$ $\mathrm{ml}$, whereas in vitro, varicella-zoster virus is inhibited by as little as $20 \mathrm{U} / \mathrm{ml}[11,22]$. (5) Recovery from a viral or other insult to the islet cell may depend upon regeneration of new islet cells and interferon might have inhibited this process despite its antiviral effects. However, if this were the reason for the lack of response during therapy, we would have expected a response in the interval following therapy, but this was not observed.

A more extensive clinical trial could not be carried out because of the limited availability of interferon. The fact that our two patients did not respond neither rules out the possibility of response in other patients nor that insulin dependent diabetes might be caused by a virus. Ideally, interferon should be tested in patients in whom a viral agent can be implicated at the onset of diabetes and in whom measurement of infectious virus or viral antigen could be carried out during interferon therapy as a marker for efficacy. 
Acknowledgements. Grand Support: Supported in part by the United States Veteran's Administration, NIH-GCRC Grant RR82, NIH AM 25403, NIH Training Grant AM 07164 and a Diabetes Center contract from the Department of Health and Rehabilitative Services of the State of Florida.

We gratefully acknowledge the technical assistance of Herbert Houck, Robert Watine, Thomas McConnell and James Jensen, the support of the staff of the Clinical Research Center, and the editorial assistance of Jacquelyn Miller and Carollene Sampley.

\section{References}

1. Fleegler FM, Rogers KD, Drash A, Rosenbloom AL, Travis LB, Court JM (1979) Age, sex, and season of onset of juvenile diabetes in different geographic areas. Pediatrics 63: 374-379

2. Gamble DR, Kinsley ML, Fitzgerald MG, Bolton R, Taylor KW (1969) Viral antibodies in diabetes mellitus. Br Med J 3: 627-630

3. Gamble DR, Taylor KW (1969) Seasonal incidence of diabetes mellitus. Br Med J 3: 631-633

4. Gamble DR, Taylor KW, Cumming H (1973) Coxsackie viruses and diabetes mellitus. Br Med J 4: 260-262

5. Gunderson E (1927) Is diabetes of infectious origin? J Infect Dis 41: 197-202

6. Yoon JW, Austin M, Onodera T, Notkins AL (1979) Virusinduced diabetes mellitus: Isolation of a virus from the pancreas of a child with diabetic ketoacidosis. N Engl J Med 300: 1173-1179

7. Champsaur K, Dussaix E, Samolyk D, Fabre M, Bach CH, Assan R (1980) Diabetes and Coxsackie virus B5 infection. Lancet I: 251

8. Messaritakis J, Karabula C, Kattamis C, Matsaniotis N (1971) Diabetes following mumps in sibs. Arch Dis Child 46: 561-562

9. Forrest JM, Menser MA, Harley JD (1969) Diabetes mellitus and congenital rubella. Pediatrics 44: 445-447

10. Greenberg HB, Pollard RB, Lutwick LI, Gregory PB, Robinson WS, Merigan TC (1976) Effect of human leukocyte interferon on hepatitis $B$ virus infection in patients with chronic active hepatitis. N Engl J Med 295: 517-522

11. Merigan TC, Rand KH, Pollard RB, Abdallah PS, Jordan GW, Fried RP (1978) Human leukocyte interferon for the treatment of herpes zoster in patients with cancer. N Engl J Med 298: $981-987$
12. Gonen B, Goldman J, Baldwin D, Goldberg RB, Ryan WG, Blix PM, Schanzlin D, Fritz KJ, Rubenstein AH (1979) Metabolic control in diabetic patients. Diabetes 28: 749-753

13. Cantell K, Hervonen S, Mogensen KE, et al (1975) Human leukocyte interferon: Production, purification and animal experiments. In: Waymouth $\mathrm{C}$ (ed) The production and use of interferon for the treatment and prevention of human virus infection. The Tissue Culture Association, Baltimore, pp $35-38$

14. Merigan TC (1971) A plaque inhibition assay for human interferon employing human neonate skin fibroblast monolayers and bovine vesicular stomatitis virus. In: Bloom BR, Glade PR (eds) In vitro methods in cell-mediated immunity. Academic Press, New York, pp 489-499

15. Block MB, Makoi ME, Steiner DF, Rubenstein AH (1972) Circulating C-peptide immunoreactivity: Studies in normals and diabetic patients. Diabetes 21: 1013-1026

16. Neufeld M, Maclaren NK, Lezotte D, McLaughlin JV, Riley WJ, Silverstein J, Rosenbloom AL (1980) Islet cell antibodies in $U$.S. Caucasians and blacks with insulin requiring diabetes. Diabetes 29: 589-592

17. Riley WJ, Neufeld M, Maclaren NK (1980) Complement fixing islet cell antibodies. A separate species? Lancet I: 1133

18. Hierholzer JC, Farris WA (1974) Follow-up of children infected in a Coxsackie virus B-3 and B-4 outbreak: No evidence of diabetes mellitus. J Infect Dis 129: 741-746

19. Dippe SE, Miller M, Bennett PH, Maynard JE, Berquist KR (1975) Lack of causal association between Coxsackie B4 virus infection and diabetes. Lancet I: 1314-1317

20. Riley W, Maclaren N, Rand KH, Bejar RL (1980) Inherited autoimmunity versus Coxsackie B4 in diabetes. Diabetes 29: $53 \mathrm{~A}$

21. Cudworth AG, White GBB, Woodrow JC, Gamble DR, Lendrum R, Bloom A (1977) Aetiology of juvenile-onset diabetes. Lancet I: $385-388$

22. Armstrong RW, Merigan TC (1971) Varicella-zoster virus: Interferon production and comparative interferon sensitivity in human cell lines. J Gen Virol 12: 53-54

Received: 18 November 1980

and in revised form: 5 March, $198 \mathbb{1}$

Dr. Kenneth Rand

Department of Medicine

Box J-277, JHM Health Center

Gainesville, Florida 32610, USA 